\title{
Carbohydrate Sulfotransferase 15
}

National Cancer Institute

\section{Source}

National Cancer Institute. Carbohydrate Sulfotransferase 15. NCI Thesaurus. Code C118524.

Carbohydrate sulfotransferase $15(561 \mathrm{aa}, \sim 65 \mathrm{kDa})$ is encoded by the human CHST 15 gene. This protein is involved in chondroitin sulfate metabolism. 